\title{
Book Reviews and Notices
}

The Lost Region: Toward a Revival of Midwestern History, by Jon K. Lauck. Iowa and the Midwest Experience Series. Iowa City: University of Iowa Press, 2013. xii, 166 pp. Notes, index. $\$ 35.00$ paperback and e-book.

Reviewer Bill Silag, former editor-in-chief at Iowa State University Press, is writing a biography of Iowa novelist Ruth Suckow.

For the past half-century there has been a decline in the attention given to the midwestern experience in the grand narrative of American history, claims author Jon K. Lauck in his new book, The Lost Region. Lauck contends that the historical study of the Midwest has been crowded out of the history curriculum at many of the region's colleges and universities in order to accommodate the emergence within the discipline of new fields of study, particularly those having to do with gender, class, and ethnicity. As a result, increasing numbers of students are now earning degrees in American history with little understanding of the important role the Midwest has played in the history of the United States. Moreover, with proportionately fewer regional specialists now teaching, there has been a concomitant decline in the production of publications focused on the region's history. "The consequence of these trends and the failure of recent generations of historians to see the Midwest as historically significant," he writes, is that the region has fallen off "the main map of American historiography and lost to the main channels of historical inquiry" (7).

The Lost Region is Lauck's impassioned response to this situation. His book is essential reading for all historians of Iowa and the Midwest. Packed with useful information for scholars and students, The Lost Region is simultaneously an extensive survey of the historiography of the state and region; an up-to-date bibliographic guide to the secondary literature of the field; and a highly charged admonition-a jeremiad really-addressed to historians of the Midwest, to join with him in an effort to revitalize a long dormant historiographical tradition and thereby restore and preserve the cultural integrity of "the lost region" at a time when the placelessness of a digital universe threatens to supplant intellectual and emotional ties to locality altogether.

As stated in its introduction, the book's purpose is to "demonstrate the importance of the Midwest, the depth of historical work once performed on the region, the continuing insights that can be 
gleaned from this body of knowledge, and the lessons that can be learned from some prominent historians that will bolster future attempts to revive the study of the American Midwest" (8). Long-term, the author's goal is to revive a midwestern regionalist historiographical tradition, quiescent for a half-century now, that once had the strength to redirect the historiography of the entire nation and to bring into being what remains today the preeminent professional organization for American historians.

The Lost Region is an extended essay in four heavily annotated chapters. In chapter one Lauck discusses "foundational events" in the eighteenth- and nineteenth-century history of the Midwest, particularly the experiences celebrated by Frederick Jackson Turner in his paradigmatic essays about the role of the frontier experience in shaping democratic social and political values in the agricultural communities of the antebellum West.

Chapters two and three focus on the Prairie Historians showcased by the author in the spring 2012 issue of the Annals of Iowa, a sizable community of scholars-including Benjamin Shambaugh and Louis Pelzer at the State University of Iowa and Louis B. Schmidt and Earle Ross of Iowa State College-whose regionalist worldview influenced much of the historical scholarship in the Midwest and beyond in the first half of the twentieth century. Inspired and encouraged by Turner, the early Prairie Historians were responsible for the formation in 1907 of the Mississippi Valley Historical Association (later renamed the Organization of American Historians) as an alternative to what was perceived by the midwesterners to be the Ivy League elitism of the establishment American Historical Association. Lauck considers their work in somewhat greater detail here than he does in the Annals of Iowa article, with an eye to demonstrating the continuing viability of their approach to historical research, albeit on updated philosophical foundations that include the pragmatic hermeneutics of intellectual historian James T. Kloppenberg. Lauck's detailed portrait of the Prairie Historians-based on extensive archival research in the manuscript collections of the individual scholars-includes information on their family backgrounds, personal and professional affiliations, and career trajectories, a major step toward the rigorous intellectual biography warranted by the rich historiographical legacy of the Prairie Historians.

Chapter four catalogs the cultural forces that contributed to the demise of the Prairie Historians in the decades after World War II, a discussion that reveals as much about the author's own regionalist proclivities as it does about the institutional and cultural forces responsible for their diminishing stature in the second half of the twenti- 
eth century. Lauck's comments here lack the sharp focus of his writing on the Prairie Historians, but his commentary on representative works from the succession of modern-day historiographical trends that undermined the midwesterners' prestige is instructive regarding perceptions of what was lost and what was gained in the process.

The book's brief epilogue considers the prospects for a revival of the Prairie tradition after a hiatus of more than fifty years. The author is sanguine about a renewal of midwestern history - and for good reason. For all the methodological and ideological controversy within the profession since the end of World War II, an enormous body of work, focused in one way or another on the Midwest, has been produced in the past half-century, much of it informed by the gender, class, and ethnicity distinctions of culture studies. "In addition to dusting off the older works of the Prairie Historians," Lauck writes, "these newer works can serve as building blocks for a more integrated history of the Midwest in the future" (85). No doubt there is plenty to work with on this score. The books and articles listed in the author's endnotes - this slender book's 90 pages of text are accompanied by 67 pages of endnotes-provide enough material to keep historians and their readers busy for years to come.

Making Marriage: Husbands, Wives and the American State in Dakota and Ojibwe Country, by Catherine J. Denial. St. Paul: Minnesota Historical Society Press, 2013. 191 pp. Illustrations, notes, bibliography, index. \$19.95 paperback, \$15.99 e-book.

Reviewer Michael Knock is assistant professor of history at Clarke University in Dubuque. His Ph.D. dissertation (University of Notre Dame, 1996) was "'Alone with Sitting Bull's People': The Dakota Indian Mission of the Congregational Church, 1870-1937."

Marriage and family have long been key elements in the making of culture on the American frontier. As Catherine J. Denial writes in Making Marriage, "When the first significant numbers of Americans arrived in the region now known as Minnesota, they did so armed with the belief that good government and an orderly household went hand in hand" (3). They weren't the only ones. Native women had their own ideas and traditions pertaining to what marriage meant: "In the clash between these systems of belief is the story of Minnesota's beginning - a complex, uneven tale which does not offer a narrative of easy triumph for the American state" (23).

Denial's book is really four different stories that center in and around Fort Snelling in the first half of the nineteenth century. The 